\title{
Variables Associated with Completeness of Medical Record Documentation in the Emergency Department
}

\author{
(Medical Record Documentation)
}

\begin{abstract}
Authors:
Dr Fiona WY Lai ${ }^{1}$ BBioMed MD

Dr Joyce A Kant ${ }^{2}$ BBioMed MD

Dr Mahesha HK Dombagolla ${ }^{3}$ BMedSci MD

Dr Andreas Hendarto ${ }^{4}$ BBioMed MD

Mr Antony Ugoni ${ }^{5} \mathrm{MSc}$

Prof David McD Taylor ${ }^{6,7}$ MBBS MD DRCOG MPH FACEM

${ }^{1}$ Intern, Royal Melbourne Hospital, Parkville, Victoria, Australia 3052

${ }^{2}$ Intern, Eastern Health, 5 Arnold St, Box Hill, Victoria, Australia 3128

${ }^{3}$ Intern, Goulburn Valley Health, 2/2-48 Graham St, Shepparton, Victoria, Australia 3630

${ }^{4}$ Intern, Bairnsdale Regional Health Service, Bairnsdale, Victoria, Australia 3875

${ }^{5}$ Senior Fellow, Centre for Epidemiology and Biostatistics, University of Melbourne, Parkville, Victoria, Australia 3052

${ }^{6}$ Director of Emergency Medicine Research, Emergency Department, Austin Hospital, Heidelberg, Australia 3084

${ }^{7}$ Professor, Department of Medicine, University of Melbourne, Parkville, Victoria, Australia 3052
\end{abstract}

\section{Corresponding Author:}

Professor David Taylor

Emergency Department, Austin Hospital

Studley Road, Heidelberg, Victoria, Australia 3084

Phone (W) +61 394964711

David.Taylor@austin.org.au

\section{Author Contribution:}

FL and DT designed the study protocol and wrote the ethics committee application. FL, JK, MD and AH collected all data. DT and AU undertook the statistical analysis. All authors contributed to preparing the study manuscript. DT supervised the study overall.

This is the author manuscript accepted for publication and has undergone full peer review but has not been through the copyediting, typesetting, pagination and proofreading process, which may lead to differences between this version and the Version of Record. Please cite this article as doi: $10.1111 / 1742-6723.13229$

This article is protected by copyright. All rights reserved. 


\begin{abstract}

\section{Objective}

The completeness of emergency department (ED) medical record documentation is often suboptimal. We aimed to determine the variables associated with documentation completeness in a large, tertiary referral ED.

\section{Methods}

We audited 1200 randomly selected medical records of patients who presented with either abdominal pain, cardiac chest pain, shortness of breath or headache between May-July 2013 and May-July 2016. Data were collected on patient and treating doctor variables.

Documentation completeness was assessed using a 0-10 point scoring tool designed for the study. A maximum score was achieved if each of 10 pre-determined important items, specific to the presenting complaint, were documented (5 medical history items, 5 physical examination items). Data were analysed using multivariate regression.

\title{
Results
}

The presenting year, day and time, patient age and gender, preferred language, interpreter requirement, discharge destination and doctor gender were not associated with documentation completeness $(\mathrm{p}>0.05)$. Patients with triage category 3 or pain score of $6-7$ had higher documentation scores $(\mathrm{p}<0.05)$. Compared to interns, registrars (effect size $-0.72,95 \% \mathrm{CI}$ 1.02 to $-0.42, \mathrm{p}<0.01)$ and consultants $(-1.62,95 \% \mathrm{CI}-1.95$ to $-1.29, \mathrm{p}<0.01)$ scored 
significantly less. The headache patient subgroup scored significantly less than the other patient subgroups $(-0.35,95 \% \mathrm{CI}-0.63$ to $-0.08, \mathrm{p}=0.01)$. For all presenting complaint subgroups, examination findings were less well documented than history items $(\mathrm{p}<0.001)$.

\section{Conclusion}

Documentation completeness is less among senior doctors, headache patients and for examination findings. Research should determine if the supervision responsibilities of senior doctors affects documentation and if medico-legal and patient care implications exist.

Keywords: documentation, emergency department, medical record 


\section{INTRODUCTION}

The medical record can be defined as documentation that contains information about a patient's medical history, symptoms, clinical findings, diagnoses, therapies and prognosis. ${ }^{1}$ It serves as a means to track the progress of a patient through the healthcare system and allows communication between healthcare providers. In addition, the medical record is important in medico-legal settings and for administration, education, research, healthcare planning and budgeting. ${ }^{1-3}$ Despite its many functions, documentation quality is often suboptimal. Suboptimal documentation is evident across multiple healthcare disciplines including nursing, pharmacy, inpatient services, outpatient services and the emergency department (ED). ${ }^{4-9}$

For many patients, the ED medical record represents the beginning of the patient's journey through different settings. Medical record entries are frequently copied from previous notes. One study reported the frequency of copied notes to be as high as $82 \% .^{10}$ This highlights the importance of good quality ED documentation. However, the time-pressured environment and high patient turnover are reported as reasons why documentation often suffers in the ED. ${ }^{11}$ Other reasons include illegible handwriting, inaccuracy, incomplete information and poor concordance. ${ }^{7,12-14}$ A number of methods have been proposed to assess documentation quality. These include the PDQI ${ }^{15}$ and QNOTE tools ${ }^{16}$ although neither has been validated in the ED setting nor adequately examine documentation completeness. 
There is a paucity of reports on the potential impact of doctor, patient and environmental factors on documentation quality, especially in the ED. We aimed to determine the variables associated with completeness (an element of quality) of medical record documentation in the ED. These variables may inform interventions aimed at improving documentation completeness in this setting. 


\section{METHODS}

We undertook a retrospective audit of electronic medical records (EMR) of the Austin Hospital ED between February and May 2017, inclusive. The Austin Hospital is a tertiary referral, metropolitan centre and the ED has a mixed (adult and paediatric) annual census of approximately 85,000 . The study was approved by the Austin Health Human Research Ethics Committee.

Prior to the audit, we developed a 'Completeness Scoring Tool' in order to evaluate the completeness of documentation in the medical record. Twelve ED consultants were independently asked to nominate the five most important items of both medical history and physical examination that should be documented for each of four common presenting complaints: abdominal pain, cardiac chest pain, shortness of breath or headache. The most commonly nominated important items informed the development of the scoring tool (see Box). If a medical record had all 10 of these important items recorded, it received a 'documentation score' of 10 . If no item was documented, the documentation score was 0.

The reproducibility of the scoring tool, when used by different assessors, was examined. Training was provided for the assessors in the use of the MEDTRAK ${ }^{\circledR}$ and CERNER ${ }^{\circledR}$ systems. A random sample of 20 patients was selected from the 1200 patients who met the study entrance criteria. The four assessors independently scored the documentation completeness of these patients. Their mean documentation scores were 5.5, 5.7, 5.8 and 5.9. 
Patients were eligible for inclusion if they were aged 18 years or more and presented in MayJuly 2013 or May-July 2016, inclusive, with one of the four presenting complaints of interest. They were excluded if they self-discharged before being assessed by an ED doctor, were reviewed by another team (not an ED doctor), or had previously been enrolled in the same 3month period. They were also excluded if their medical record or demographic details were missing or if they had no ED doctor notes (the patient was seen by a nurse practitioner or physiotherapist). From each year's list, 600 eligible patients (150 patients for each of the four presenting complaint groups) were randomly selected, using the Excel randomization function.

In both the MEDTRAK ${ }^{\circledR}$ (introduced in 2001) and CERNER $^{\circledR}$ (introduced in 2014) ED information systems, all medical records were typed into the computer directly by the treating doctor. No records were handwritten. A single investigator (FL) extracted all data from the medical records. These data included presenting year, day and time, patient age and gender, triage category, pain score, preferred language, interpreter requirement, discharge destination, presenting complaint, doctor gender and designation. A document with the definitions and inclusions for the scoring criteria assisted data extraction (see Appendix). Any uncertainty on the definition of the nominated items was clarified with an ED consultant.

Following data collection, a sample of $10 \%$ of enrolled patients was randomly selected and their medical record scored by a second assessor. Any discrepancy in completeness scores between the original and second assessors was re-checked against the definitions document to inform the final scoring. Scores between any two assessors were concordant in $82.5 \%$ of 
cases. In all but one of the discordant cases, the assessor scores differed by 1 . For the other case, the scores differed by 2 .

Data were entered into an Excel spreadsheet without identifying information. All patients were assigned a study ID number. A password protected master list linking the patient's name and UR number to the study ID number was generated to enable a subsequent data extraction accuracy exercise.

The primary outcome of the study was documentation completeness as measured by the scoring tool (range 0-10). Secondary outcomes included a comparison of completeness between the presenting complaint and doctor subgroups, and history and examination item completeness.

A difference of one, in the mean documentation scores of related variable subgroups (e.g. male versus female patients), was considered to be clinically significant. In order to demonstrate a statistically significant difference between the mean documentation scores of two variable subgroups, at least 141 patients were needed in each subgroup (difference in means of 1 , SD 3, level of significance 0.05 , 2-sided, power 0.8 ). However, some variables had four subgroups (e.g. age classification) and it was expected that patient numbers in each subgroup would differ. To account for these issues, we set the total sample size at 1200 patients (300 from each of the four presenting complaint groups). 
Most analyses were descriptive e.g. mean (SD), proportion $(95 \% \mathrm{CI})$. Multivariate regression was employed to determine which doctor, patient or environmental variables were associated with the documentation completeness score. Intercooled Stata 6.0 for Windows 98/95/NT (Stata Corporation, College Station, Texas, USA) was employed for all analyses (level of significance 0.05$)$. 


\section{RESULTS}

A total of 1200 electronic medical records completed by 195 doctors was analysed. A description of the variables of interest are reported in Table 1. There were few differences in the following variables: presenting year, patient gender, presenting complaint and doctor gender. There was a higher proportion of weekday than weekend presentations and a lower proportion of presentations during the time 0000-0759 and among patients aged over 80 years. Most patients spoke English and did not require an interpreter. There were also small differences in the number of interns and residents compared to registrars and consultants. Presentations that were classified as triage category 3 were most common. Additionally, there were slightly fewer patients with mild and severe pain (as opposed to moderate pain) and fewer who were transferred to the short stay ward.

The univariate and multivariate regression results are reported in Table 1. The designation of the doctor was significantly associated with documentation completeness. As seniority increased, documentation completeness decreased. Doctor gender was associated with completeness in the univariate but not the multivariate analyses.

Patients with triage category 3 or in moderate pain had slightly higher documentation scores when compared to their respective reference subgroups. However, the differences between the mean scores between the groups were not clinically significant ( 0.2 and 0.1 , respectively). Patients in the headache subgroup had slightly lower scores than the abdominal pain subgroup. However, the differences in the mean scores for these complaints $(<1)$ were not 
clinically significant. The presenting year, day and time, patient age and gender, triage category, pain score, preferred language, interpreter requirement, discharge destination were not associated with documentation completeness.

For each presenting complaint, a maximum of 1500 history and 1500 examination items could have been documented ( 5 items x 300 patients). For each of the presenting complaint groups, documentation of examination items was significantly less than history items (Table 2). The most poorly documented history items were precipitating/exacerbating factors of chest pain and fever in headache, both of which were documented less than $55 \%$ of the time (Table 3). The most poorly documented examination items were abdominal distension, jugular venous pressure and eye exam, where each item was documented less than $30 \%$ of the time.

This article is protected by copyright. All rights reserved. 


\section{DISCUSSION}

This study demonstrates that seniority of the doctor is significantly and negatively associated with completeness of the ED medical record, a component of documentation quality. This finding is consistent with other reports. Chong et al. ${ }^{17}$ examined the effect of an EMR system on documentation quality and reported that senior doctors performed more poorly on a template EMR system than junior doctors. Soto et al. ${ }^{18}$ examined variables affecting documentation quality and reported that more senior physicians were less likely to document drug allergies or immunisation status.

Explanations for these consistent findings are difficult to determine. Although speculation, it may be that interns are more diligent and record more information, including lists of negative findings. Interns usually see fewer patients and may spend more time on documentation. Moreover, they may have better typing and computer skills that allows them time to record more information. All doctors in our ED see new patients. However, senior doctors have more responsibilities, including managing patient flow, supervision of junior doctors and medical students, management plans, administration and teaching. These may limit their time available for more complete documentation.

Importantly, this study explored only documentation in the medical record. It is possible that the senior doctors did, in fact, ascertain and use information on most or all of the important history and examination items. Indeed, they may have performed better in this regard than the junior staff. So, no association can be drawn between documentation completeness and the actual quality of patient assessment. 
Although we did not find an association between doctor gender documentation completeness, Soto et al. ${ }^{18}$ showed that female physicians have better smoking history documentation than males and that female paediatricians are more likely to document drug allergies. They also reported that documentation completeness varied with specialisation of the doctor. As our study was confined to the ED setting, we were unable to investigate this variable. It is logical to assume, however, that with different specialties, the focus of the history and exam is skewed to the specialty of interest.

Daphtary et al. ${ }^{19}$, using the PDQI-9 tool, reported no association between documentation quality and the time of presentation to a paediatric intensive care unit (ICU). This was consistent with our findings where time and day of presentation were not associated with documentation completeness. Conversely, another ICU study showed that transcription of laboratory results was more accurate when recorded in the morning. ${ }^{20}$

Documentation of headache items was slightly less complete than the other presenting complaint subgroups. In particularly, the eye examination was the least well documented. As the examination items for this complaint are more time consuming than the other complaints, this may have contributed to this finding. Overall, in each patient subgroup, history items were more frequently documented. This may reflect the perception that history is often more important than examination in patient assessment.

Given the important role medical records have for communication between healthcare providers, it is important that all the relevant information is documented and accurate. Most investigators agree that 
documentation quality is associated with quality of care. ${ }^{21,22}$ Zeger et al. ${ }^{21}$ reported that poor documentation quality is associated with the adverse event rate. Poor documentation has also been found to hinder assessment of the quality of care delivered to patients. ${ }^{23}$

In addition to implications for patient care, poor documentation quality may have medico-legal implications. ${ }^{24,25}$ Medical records are legal documents and good documentation is the most concrete defence when proving whether something was done. Documentation is less fallible and less subjective than an individual's testimony. ${ }^{26}$

There are recommendations on what to include in medical records and how to improve documentation. ${ }^{25,27,28}$ Doctors, regardless of seniority, should endeavour to document well and include all important items relevant to the presenting complaint. Professional development workshops and individualised feedback have been shown to improve medical record quality ${ }^{29,30}$ and could be considered by institutions and individual EDs. Furthermore, there is scope for the Australasian College for Emergency Medicine to determine documentation benchmarks within our EDs and means of achieving these.

\section{Limitations}

Only electronic records on MEDTRAK and CERNER were assessed and they may not be representative of other EMR systems. We examined only ED documentation so our findings may not be relevant to other healthcare settings e.g. inpatient or outpatient encounters. Furthermore, the findings are only applicable to the four common presenting complaints examined. Also, the completeness scoring tool was designed specifically for this study and has not been used or validated 
elsewhere. However, when used by different assessors for the same records, the score reproducibility was good. The tool was comprised of items as determined by 12 emergency physicians and their responses often varied. As such, they may not have been the most important items within a medical record. However, the tool was applied consistently and was able to compare documentation completeness, regardless of the absolute importance of all tool items. In some cases, an item may not have been documented if it was not of relevance to that particular presentation e.g. a straight forward case not requiring a complete evaluation. Hence, a low documentation score does not necessarily mean poor documentation. Our study did not capture other measures of quality such as accuracy and reliability and did not address whether documentation quality affects quality of care. Finally, as a single centre study, the external validity of the findings may be questionable. 


\section{CONCLUSION}

Registrar and consultant documentation is less complete than that of interns. History items are better documented than examination items for each of the four presenting complaints. Headache items were documented slightly less well than those for the other presenting complaints. Further research should determine the extent of medico-legal and patient care implications of poor documentation and whether the documentation of senior doctors needs to be improved.

This article is protected by copyright. All rights reserved. 


\section{ACKNOWLEGDEMENTS}

The authors acknowledge the emergency physicians who contributed to the development of the scoring tool.

This study was unfunded.

There are no competing interests to declare.

The authors will make available the study data upon request to the Corresponding Author.

This article is protected by copyright. All rights reserved. 


\section{REFERENCES}

1. Hannah KP, Ball MJ. Health Informatics. 1st ed. United States of America: Springer-Verlag New York, Inc; 2003. 1-2 p.

2. Elkin PL, Trusko BE, Koppel R, Speroff T, Mohrer D, Sakji S, et al. Secondary use of clinical data. Stud Health Technol Inform. 2010; 155: 14-29

3. Kristianson KJ, Ljunggren H, Gustafsson LL. Data extraction from a semi-structured electronic medical record system for outpatients: a model to facilitate the access and use of data for quality control and research. Health Informatics $J .2009 ; 15: 305-319$

4. Wood C. The importance of good record-keeping for nurses. Nurs Times. 2003; 99: 26-27

5. Elliott RA, Woodward MC, Oborne CA. Quality of prescribing for elderly inpatients at nine hospitals in Victoria, Australia. J Pharm Pract Res. 2003; 33: 101-105

6. Ernst ME, Brown GL, Klepser TB, Kelly MW. Medication discrepancies in an outpatient electronic medical record. Am J Health Syst Pharm. 2001; 58: 2072-2075

7. Lau HS, Florax C, Porsius AJ, De Boer A. The completeness of medication histories in hospital medical records of patients admitted to general internal medicine wards. Br J Clin Pharmacol. 2000; 49: 597-603

8. Osborn GD, Pike H, Smith M, Winter R, Vaughan-Williams E. Quality of clinical case note entries: How good are we at achieving set standards? Ann R Coll Surg Engl. 2005; 87: 458460

9. Salazar L, Best TM, Hiestand B. Incomplete documentation of elements of Ottawa Ankle Rules despite an electronic medical record. Am J Emerg Med. 2011; 29: 999-1002

10. Thornton JD, Schold JD, Venkateshaiah L, Lander B. Prevalence of copied information by 
attendings and residents in critical care progress notes. Crit Care Med. 2013; 41: 382-388

11. Yu KT, Green RA. Critical Aspects of Emergency Department Documentation and Communication. Emerg Med Clin North Am. 2009; 27: 641-654

12. Boehringer PA, Rylander J, Dizon DT, Peterson MW. Improving the quality of the orderwriting process for inpatient orders in a teaching hospital. Qual Manag Health Care. 2007; 16: $215-218$

13. Dexter SC, Hayashi D, Tysome JR. The ANKLe score: an audit of otolaryngology emergency clinic record keeping. Ann R Coll Surg Engl. 2008; 90: 231-234

14. Ehrenberg A, Margareta E. The accuracy of patient records in Swedish nursing homes: Congruence of record content and nurses' and patients' descriptions. Scand J Caring Sci. $2001 ; 15: 303-310$

15. Stetson PD, Morrison FP, Bakken S, Johnson SB, eNote Research T. Preliminary development of the physician documentation quality instrument. $J$ Am Med Inform Assoc. 2008; 15: 534-541

16. Burke HB, Hoang A, Becher D, Fontelo P, Liu F, Stephens M, et al. QNOTE: an instrument for measuring the quality of EHR clinical notes. $J$ Am Med Inform Assoc. 2014; 21: 910-916

17. Lee FC, Chong WF, Chong P, Ooi SB. The emergency medicine department system: a study of the effects of computerization on the quality of medical records. Eur J Emerg Med. 2001; 8: $107-115$

18. Soto CM, Kleinman KP, Simon SR. Quality and correlates of medical record documentation in the ambulatory care setting. BMC Health Serv Res. 2002; 2: 22

19. Daphtary K. Computerized clinical documentation in the pediatric intensive care unit / : quality of notes and factors that affect the quality. Masters Thesis. 2014 
20. Black R, Woolman P, Kinsella J. Variation in the transcription of laboratory data in an intensive care unit. Anaesthesia. 2004; 59: 767-769

21. Zegers M, de Bruijne MC, Spreeuwenberg P, Wagner C, Groenewegen PP, van der Wal G. Quality of patient record keeping: an indicator of the quality of care?. BMJ Qual Saf. 2011; 20: $314-318$

22. Cox JL, Zitner D, Courtney KD, MacDonald DL, Paterson G, Cochrane B, et al. Undocumented patient information: an impediment to quality of care. Am J Med. 2003; 114: 211-216

23. Abernethy AP, Herndon JE, Wheeler JL, Rowe K, Marcello J, Patwardhan M. Poor Documentation Prevents Adequate Assessment of Quality Metrics in Colorectal Cancer. $J$ Oncol Pract. 2009; 5: 167-174. Available from URL: https://doi.org/10.1200/JOP.0942003 (last accessed July 17, 2018)

24. The consequences of an incomplete medical record [Internet]. Staff Development Weekly: Insight on Evidence-Based Practice in Education. 2005 [cited 2017 Jun 30]. Available from URL: http://www.hcpro.com/NRS-53207-975/The-consequences-of-an-incomplete-medicalrecord.html (last accessed July 17, 2018)

25. Why good documentation matters [Internet]. The Canadian Medical Protective Association. 2011 [cited 2017 Jun 30]. Available from URL:

http://www.cpso.on.ca/cpso/media/uploadedfiles/members/peerassessment/documentationcmpa.pdf (last accessed July 17, 2018)

26. Hafter J, Fedor V. EMS and the Law. 1st ed. United States: Jones and Bartlett Publishers, Inc; 2004. $85 \mathrm{p}$.

27. Medical Records. Avant. [cited 2017 Jun 30]. Available from URL: 
http://www.avant.org.au/resources/start-a-practice/practice-operations/systems-andprocedures/medical-records/ (last accessed July 17, 2018)

28. The Medical Board of Australia. Good Medical Practice: A code of conduct for doctors in Australia. March 2014. Available at URL: https://www.medicalboard.gov.au/CodesGuidelines-Policies/Code-of-conduct.aspx (last accessed October 22, 2018)

29. Fox AT, Palmer RD, Crossley JGM, Sekaran D, Trewavas ES, Davies HA. Improving the quality of outpatient clinic letters using the Sheffield Assessment Instrument for Letters (SAIL). Med Educ. 2004; 38: 852-858

30. Mclean A, Lawlor J, Mitchell R, Kault D, O'Kane C, Lees M. Impact of a structured intern education programme on clinical documentation in the emergency department. Emerg Med Australas. 2015; 27: 29-34 
Box. History and examination items that comprise the documentation completeness scoring tool

\begin{tabular}{|c|c|c|}
\hline presenting complaint & history items & examination items \\
\hline \multirow[t]{5}{*}{ abdominal pain } & past history & general appearance \\
\hline & duration & local tenderness \\
\hline & location & peritonism \\
\hline & bowel motions & distension \\
\hline & vomiting & bowel sounds \\
\hline \multirow[t]{5}{*}{ cardiac chest pain } & past history & general appearance \\
\hline & duration & lung auscultation \\
\hline & nature & heart auscultation \\
\hline & precipitating/exacerbating factors & jugular venous pressure \\
\hline & associated symptoms & peripheral oedema \\
\hline \multirow[t]{5}{*}{ shortness of breath } & past history & lung auscultation \\
\hline & duration & heart auscultation \\
\hline & fever & jugular venous pressure \\
\hline & cough & peripheral oedema \\
\hline & associated pain & accessory muscle use \\
\hline \multirow[t]{5}{*}{ headache } & past history & general appearance \\
\hline & duration & meningism \\
\hline & site & cranial nerve exam \\
\hline & fever & peripheral neurological exam \\
\hline & associated symptoms & eye exam \\
\hline
\end{tabular}

This article is protected by copyright. All rights reserved. 
Table 1. Regression analysis of variables on documentation scores

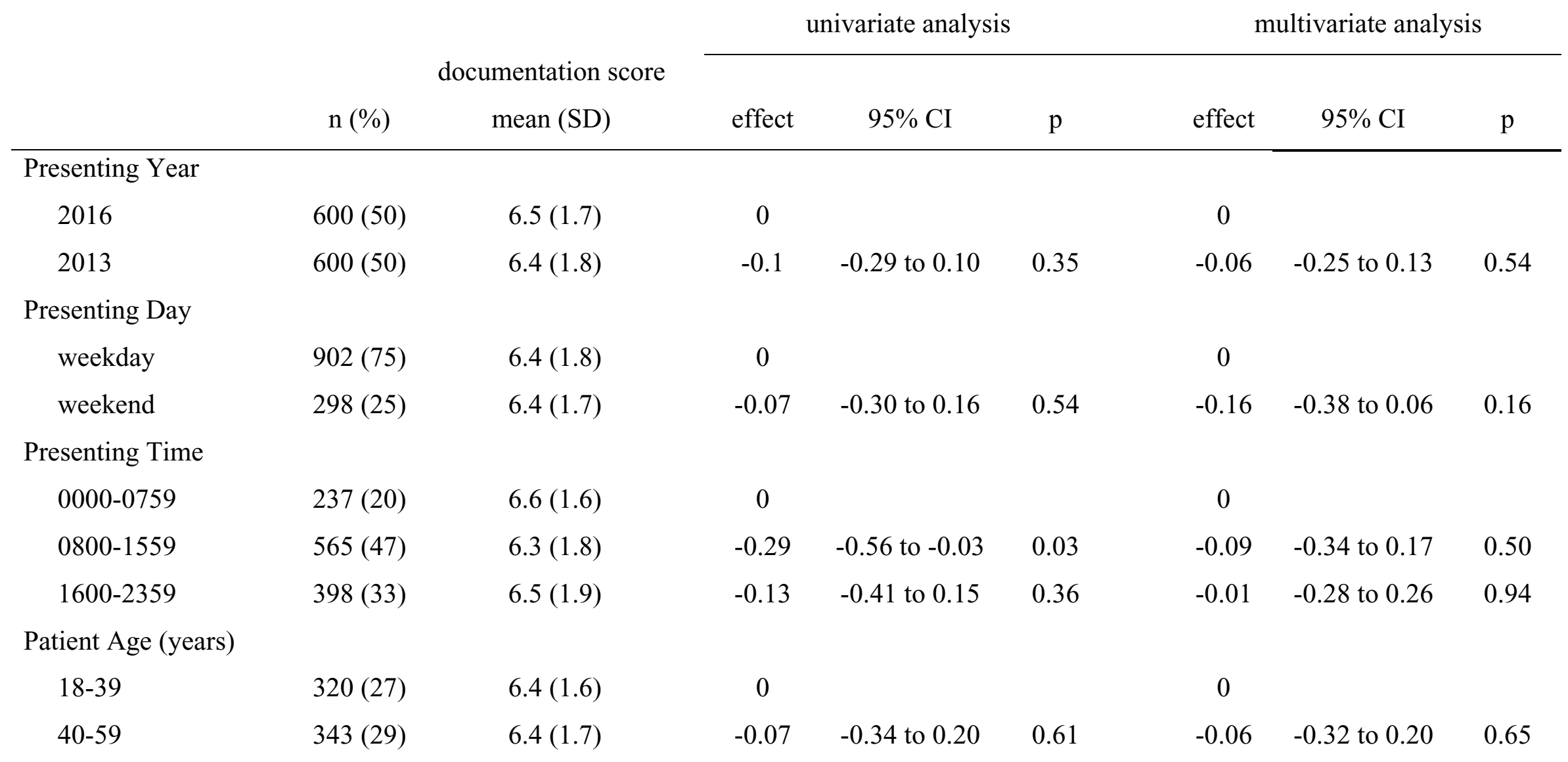




\begin{tabular}{|c|c|c|c|c|c|c|c|c|}
\hline $60-79$ & $340(28)$ & $6.4(1.8)$ & -0.07 & -0.34 to 0.20 & 0.61 & 0.001 & -0.29 to 0.29 & 0.995 \\
\hline $80+$ & $197(16)$ & $6.7(1.8)$ & 0.22 & -0.09 to 0.54 & 0.16 & 0.29 & -0.06 to 0.65 & 0.10 \\
\hline \multicolumn{9}{|l|}{ Patient Gender } \\
\hline male & $488(41)$ & $6.4(1.8)$ & 0 & & & 0 & & \\
\hline female & $712(59)$ & $6.4(1.7)$ & -0.02 & -0.23 to 0.18 & 0.82 & 0.13 & -0.19 to 0.21 & 0.90 \\
\hline \multicolumn{9}{|l|}{ Presenting Complaint } \\
\hline abdominal pain & $300(25)$ & $6.6(1.6)$ & 0 & & & 0 & & \\
\hline cardiac chest pain & $300(25)$ & $6.5(1.8)$ & -0.05 & -0.32 to 0.23 & 0.74 & 0.23 & -0.12 to 0.60 & 0.20 \\
\hline shortness of breath & $300(25)$ & $6.5(2.0)$ & -0.11 & -0.39 to 0.17 & 0.44 & 0.12 & -0.25 to 0.49 & 0.52 \\
\hline headache & $300(25)$ & $6.2(1.6)$ & -0.38 & -0.66 to -0.10 & 0.01 & -0.35 & -0.63 to -0.08 & 0.01 \\
\hline \multicolumn{9}{|l|}{ Triage Category } \\
\hline $1-2$ & $335(28)$ & $6.3(1.7)$ & 0 & & & 0 & & \\
\hline 3 & $638(53)$ & $6.5(1.8)$ & 0.15 & -0.08 to 0.39 & 0.19 & 0.27 & 0.002 to 0.53 & 0.048 \\
\hline $4-5$ & $22719)$ & $6.3(1.8)$ & -0.13 & -0.31 to 0.28 & 0.93 & 0.3 & -0.06 to 0.65 & 0.10 \\
\hline \multicolumn{9}{|l|}{ Preferred Language } \\
\hline English & $1079(91)$ & $6.4(1.7)$ & 0 & & & 0 & & \\
\hline other & $121(9)$ & $6.5(1.9)$ & 0.08 & -0.25 to 0.41 & 0.63 & -0.31 & -0.81 to 0.18 & 0.22 \\
\hline
\end{tabular}


no

yes

Pain intensity at triage

none (pain score 0 )

mild (1-3)

moderate (4-7)

severe pain (8-10)

Discharge Destination ${ }^{\dagger}$

home

short stay unit

inpatient Ward

Doctor Gender

$$
\text { male }
$$

female

Doctor Designation

$\begin{array}{lll}\text { intern } & 156(13) & 7.2(1.6) \\ \text { resident } & 192(16) & 7.0(1.4) \\ \text { registrar } & 544(45) & 6.5(1.6)\end{array}$

\section{$6.4(1.8)$}

$6.7(1.8)$

$$
6.4(2.0)
$$$$
6.5(1.8)
$$

$6.4(1.5)$

$$
545(45)
$$$$
271(23)
$$

383 (32)

$$
6.5(1.8)
$$$$
6.4 \text { (1.7) }
$$$$
6.4(1.7)
$$

$$
684(57)
$$$$
6.7(1.7)
$$

$$
516(43)
$$

0

0.26

-0.14 to 0.66

0.2

0

$0.54-0.05$ to $1.13 \quad 0.07$

$0.05 \quad-0.24$ to $0.34 \quad 0.73$

$\begin{array}{lll}0.05 & -0.20 \text { to } 0.29 \quad 0.71\end{array}$

$-0.04 \quad-0.35$ to $0.28 \quad 0.81$

\section{0}

$-0.12$

$-0.09$

-0.38 to 0.13

-0.32 to 0.14

0.36

0.45

0

0.39

0.19 to 0.59

$<0.01$

0

$\begin{array}{lll}-0.22 & -0.57 \text { to } 0.13 & 0.22\end{array}$

$-0.74-1.03$ to $-0.44<0.01$
0

$0.26-0.06$ to $0.58 \quad 0.11$

$0.35 \quad 0.03$ to $0.67 \quad 0.03$

$\begin{array}{lll}0.36 & -0.05 \text { to } 0.77 \quad 0.08\end{array}$

\section{0}

$\begin{array}{lll}-0.002 & -0.26 \text { to } 0.25 \quad 0.99\end{array}$

$-0.11-0.35$ to $0.14 \quad 0.39$

\section{0}

$0.16-0.04$ to $0.35 \quad 0.11$

0

$-0.23-0.58$ to $0.13 \quad 0.21$

$-0.72-1.02$ to $-0.42<0.01$ 
Table 2. Difference in proportions of documented history and examination items

\begin{tabular}{lcccc} 
& history items & exam items & difference in & \\
complaint & $\mathrm{n}^{\dagger}=1500$ & $\mathrm{n}^{\dagger}=1500$ & proportions & $\mathrm{p}$ \\
& & & $\%(95 \% \mathrm{CI})$ & \\
& & & & \\
\hline abdominal pain, $\mathrm{n}(\%)$ & $1254(83.6)$ & $719(47.9)$ & $35.7(32.5,38.9)$ & $<0.001$ \\
cardiac chest pain, $\mathrm{n}(\%)$ & $1125(75.0)$ & $823(54.9)$ & $20.1(16.7,23.5)$ & $<0.001$ \\
shortness of breath, $\mathrm{n}(\%)$ & $1133(75.5)$ & $787(52.5)$ & $23.1(19.7,26.5)$ & $<0.001$ \\
headache, $\mathrm{n}(\%)$ & $1227(81.8)$ & $639(42.6)$ & $39.2(36.0,42.4)$ & $<0.001$
\end{tabular}

${ }^{\dagger} \mathrm{n}=5$ important items/patient $\times 300$ patients $=1500$ items should have been documented 
Table 3. History and examination items recorded in the medical record complaint $\quad$ history items, $\mathrm{n}^{\dagger}(\%) \quad$ examination items, $\mathrm{n}^{\dagger}(\%)$

\begin{tabular}{|c|c|c|c|c|}
\hline abdominal & past history & $267(89.0)$ & general appearance & $151(50.3)$ \\
\hline \multirow[t]{4}{*}{ pain } & duration (onset) & $283(94.3)$ & local tenderness & $278(92.7)$ \\
\hline & location & $267(89.0)$ & peritonism & $96(32.0)$ \\
\hline & bowel motions & $233(77.7)$ & distension & $42(14.0)$ \\
\hline & vomiting & $204(68.0)$ & bowel sounds & $152(50.7)$ \\
\hline \multirow{5}{*}{$\begin{array}{l}\text { cardiac chest } \\
\text { pain }\end{array}$} & past history & $273(91.0)$ & general appearance & $134(44.7)$ \\
\hline & duration (onset) & $292(97.3)$ & lung auscultation & $258(86.0)$ \\
\hline & nature & $202(67.3)$ & heart auscultation & $237(79.0)$ \\
\hline & exacerbating factors & $99(33.0)$ & jugular venous pressure & $77(25.7)$ \\
\hline & associated symptoms & $259(86.3)$ & peripheral oedema & $117(39.0)$ \\
\hline \multirow{5}{*}{$\begin{array}{l}\text { shortness of } \\
\text { breath }\end{array}$} & past history & $288(96.0)$ & lung auscultation & $274(91.3)$ \\
\hline & duration (onset) & $269(89.7)$ & heart auscultation & $192(64.0)$ \\
\hline & fever & $184(61.0)$ & jugular venous pressure & $85(28.3)$ \\
\hline & cough & $206(69.0)$ & peripheral oedema & $139(46.3)$ \\
\hline & associated pain & $186(62.0)$ & accessory muscle & $97(32.3)$ \\
\hline \multirow[t]{4}{*}{ headache } & past history & $269(89.7)$ & general appearance & $130(43.3)$ \\
\hline & duration (onset) & $292(97.3)$ & meningism & $115(38.3)$ \\
\hline & site & $222(74.0)$ & cranial nerve exam & $185(61.7)$ \\
\hline & fever & $280(54.7)$ & peripheral neuro exam & $186(62.0)$ \\
\hline
\end{tabular}




$$
\text { associated symptoms } 130(93.3)
$$

eye exam

$23(7.7)$

${ }^{\dagger} \mathrm{n}=$ number of times an item was documented out of a maximum of 300 for each presenting complaint in 300 patients 
Appendix. Definitions of presenting complaint history and examination items

\begin{tabular}{|c|c|c|}
\hline $\begin{array}{l}\text { Presenting } \\
\text { complaint }\end{array}$ & History Items & Exam Items \\
\hline \multirow{5}{*}{$\begin{array}{l}\text { Abdominal } \\
\text { Pain }\end{array}$} & $\begin{array}{l}\text { Past History } \\
\text { Relevant past history either of the same } \\
\text { presentation or conditions that may } \\
\text { present with ABDP. } \\
\text { If they have specified there is "nil } \\
\text { PMHx" in the free text, this also scores a } \\
1 .\end{array}$ & $\begin{array}{l}\text { General Appearance } \\
\text { Mention of whether they look well or } \\
\text { unwell or whether they are comfortable } \\
\text { +/- body habitus, body position they are } \\
\text { in, +/- other comments like "looks } \\
\text { miserable, distressed or pale/ sweaty" } \\
\text { Do not accept "alert", "oriented" or } \\
\text { "anxious" alone as adequate for general } \\
\text { appearance. }\end{array}$ \\
\hline & $\begin{array}{l}\text { Duration } \\
\text { When did it first start? +/- how quickly } \\
\text { did it come on. }\end{array}$ & $\begin{array}{l}\text { Local Tenderness } \\
\text { Do they specify where it is they are } \\
\text { tender? }\end{array}$ \\
\hline & $\begin{array}{l}\text { Location } \\
\text { Does it specify which quadrant, mention } \\
\text { that it's generalised or specific location? } \\
\text { Flank pain on its own does not count - } \\
\text { EXCLUDE PATIENT }\end{array}$ & $\begin{array}{l}\text { Peritonism } \\
\text { Mention of the absence/presence of } \\
\text { rebound tenderness, percussion } \\
\text { tenderness, or that the patient is lying } \\
\text { very still. } \\
\text { * mention of guarding is not enough. }\end{array}$ \\
\hline & $\begin{array}{l}\text { Bowel Motions } \\
\text { Mention of time when bowels last open } \\
\text { or whether they are } \\
\text { active/constipated/have diarrhoea. }\end{array}$ & $\begin{array}{l}\text { Distension } \\
\text { Any comments of abdominal distension; } \\
\text { either yes or no. }\end{array}$ \\
\hline & $\begin{array}{l}\text { Vomiting } \\
\text { Documentation of nil vomiting or } \\
\text { vomiting with further details. }\end{array}$ & $\begin{array}{l}\text { Bowel Sounds } \\
\text { Mention of whether they are present, } \\
\text { normal or specific characteristics. }\end{array}$ \\
\hline
\end{tabular}




\begin{tabular}{|c|c|c|}
\hline \multirow{5}{*}{$\begin{array}{c}\text { Cardiac } \\
\text { Chest Pain }\end{array}$} & $\begin{array}{l}\text { Past History } \\
\text { Relevant past history either of the same } \\
\text { presentation or conditions that may } \\
\text { present with ABDP. } \\
\text { If they have specified there is "nil } \\
\text { PMHx" in the free text, this also scores a } \\
1 .\end{array}$ & $\begin{array}{l}\text { General Appearance } \\
\text { Mention of whether they look well or } \\
\text { unwell or whether they are comfortable } \\
\text { +/- body habitus, body position they are } \\
\text { in, +/- other comments like "looks } \\
\text { miserable, distressed or pale/ sweaty" } \\
\text { Do not accept "alert", "oriented" or } \\
\text { "anxious" alone as adequate for general } \\
\text { appearance. }\end{array}$ \\
\hline & $\begin{array}{l}\text { Duration } \\
\text { When did it first start? +/- how quickly } \\
\text { did it come on. }\end{array}$ & $\begin{array}{l}\text { Lung Auscultation } \\
\text { Documented auscultation findings } \\
\text { whether that be "chest clear" or abnormal } \\
\text { findings. }\end{array}$ \\
\hline & $\begin{array}{l}\text { Nature } \\
\text { Description of the quality of the pain } \\
\text { (radiation does not count) }\end{array}$ & $\begin{array}{l}\text { Heart Auscultation } \\
\text { Documented auscultation findings of } \\
\text { either "HSDNM" or abnormal findings. }\end{array}$ \\
\hline & $\begin{array}{l}\text { Precipitation/Exacerbating Factors } \\
\text { Mention of what brought the pain on or } \\
\text { what makes it worse. } \\
\text { Documentation of "no exacerbating } \\
\text { factors" also scores } 1 .\end{array}$ & $\begin{array}{l}\boldsymbol{J V P} \\
\text { Documentation of JVP level }\end{array}$ \\
\hline & $\begin{array}{l}\text { Associated Symptoms } \\
\text { Mention of the presence/absence of any } \\
\text { symptoms such as diaphoresis, SOB, } \\
\text { nausea, palpitations, dizziness etc. }\end{array}$ & $\begin{array}{l}\text { Peripheral Oedema } \\
\text { Mention of any or no peripheral oedema. } \\
\text { May include abbreviations like "SOA" = } \\
\text { swelling of ankles. }\end{array}$ \\
\hline $\begin{array}{c}\text { Shortness of } \\
\text { Breath }\end{array}$ & $\begin{array}{l}\text { Past History } \\
\text { Relevant past history either of the same } \\
\text { presentation or conditions that may } \\
\text { present with ABDP. } \\
\text { If they have specified there is "nil }\end{array}$ & $\begin{array}{l}\text { Lung Auscultation } \\
\text { Documented auscultation findings } \\
\text { whether that be "chest clear" or abnormal } \\
\text { findings. }\end{array}$ \\
\hline
\end{tabular}




\begin{tabular}{|c|c|c|}
\hline & $\begin{array}{l}\text { PMHx" in the free text, this also scores a } \\
\text { 1. Duration - when did it first start? +/- } \\
\text { how quickly did it come on. }\end{array}$ & \\
\hline & $\begin{array}{l}\text { Duration } \\
\text { When did it first start? +/- how quickly } \\
\text { did it come on. }\end{array}$ & $\begin{array}{l}\text { Heart Auscultation } \\
\text { Documented auscultation findings of } \\
\text { either "HSDNM" or abnormal findings. }\end{array}$ \\
\hline & $\begin{array}{l}\text { Fever } \\
\text { Either documented fevers or noted as } \\
\text { afebrile. Can count lay terms such as } \\
\text { patient felt feverish but did not measure } \\
\text { their temperature. }\end{array}$ & $\begin{array}{l}\boldsymbol{J V P} \\
\text { Documentation of JVP level }\end{array}$ \\
\hline & $\begin{array}{l}\text { Cough } \\
\text { Documented of presence or absence of } \\
\text { cough. May include quality of cough. }\end{array}$ & $\begin{array}{l}\text { Peripheral Oedema } \\
\text { Mention of any or no peripheral oedema. } \\
\text { May include abbreviations like "SOA" = } \\
\text { swelling of ankles. }\end{array}$ \\
\hline & $\begin{array}{l}\text { Associated Pain } \\
\text { Mention of the presence/absence of any } \\
\text { symptoms such as pleuritic chest } \\
\text { pain/cardiac chest pain/traumatic pain or } \\
\text { leg pain. }\end{array}$ & $\begin{array}{l}\text { Accessory Muscle Use } \\
\text { Is it documented specifically? } \\
\text { Mentioning WOB/respiratory distress } \\
\text { can also count for accessory muscle use. } \\
\text { Documentation of patient's ability to } \\
\text { speak in long or full sentences also } \\
\text { scores } 1 . \\
\text { "Patient looks SOB" will score } 1 .\end{array}$ \\
\hline Headache & $\begin{array}{l}\text { Past History } \\
\text { Relevant past history either of the same } \\
\text { presentation or conditions that may } \\
\text { present with ABDP. } \\
\text { If they have specified there is "nil } \\
\text { PMHx" in the free text, this also scores a } \\
1 .\end{array}$ & $\begin{array}{l}\text { General Appearance } \\
\text { Mention of whether they look well or } \\
\text { unwell or whether they are comfortable } \\
\text { +/- body habitus, body position they are } \\
\text { in, +/- other comments like "looks } \\
\text { miserable, distressed or pale/ sweaty" } \\
\text { Do not accept "alert", "oriented" or }\end{array}$ \\
\hline
\end{tabular}




\begin{tabular}{|c|c|}
\hline & $\begin{array}{l}\text { "anxious" alone as adequate for general } \\
\text { appearance. }\end{array}$ \\
\hline $\begin{array}{l}\text { Duration } \\
\text { When did it first start? +/- how quickly } \\
\text { did it come on. }\end{array}$ & $\begin{array}{l}\text { Meningism } \\
\text { Testing documented for neck stiffness } \\
\text { and photophobia +/- Brudzinski's sign. } \\
\text { * Brudzinski's sign = severe neck } \\
\text { stiffness causes a patient's hips and knees } \\
\text { to flex when the neck is flexed. }\end{array}$ \\
\hline $\begin{array}{l}\text { Site } \\
\text { Description of location of headache. Eg. } \\
\text { generalised, temporal, one sided, } \\
\text { occipital or band across the head. }\end{array}$ & $\begin{array}{l}\text { Cranial Nerve Exam } \\
\text { Full cranial nerve exam performed (if } \\
\text { they omit steps like gag reflex, this is still } \\
\text { acceptable). } \\
\text { Please score } 1 \text { if they use a collective } \\
\text { term regarding neurological status. Eg. } \\
\text { "neurologically intact", "nil focal neuro } \\
\text { signs" or "neuro exam NAD" }\end{array}$ \\
\hline $\begin{array}{l}\text { Fever } \\
\text { Either documented fevers or noted as } \\
\text { afebrile. Can count lay terms such as } \\
\text { patient felt feverish but did not measure } \\
\text { their temperature. }\end{array}$ & $\begin{array}{l}\text { Peripheral Neurological Exam } \\
\text { Must include upper limb and lower limb } \\
\text { neurological exam of both motor and } \\
\text { sensory domains. } \\
\text { If they document "Neurological exam } \\
\text { completed/NAD", please score } 1 . \\
\text { If they say "No neurological deficit" or } \\
\text { "No neurological signs" or "No focal } \\
\text { deficit, please score } 1 .\end{array}$ \\
\hline $\begin{array}{l}\text { Associated Symptoms } \\
\text { Mention of the presence/absence of any } \\
\text { symptoms such as photophobia, neck } \\
\text { stiffness, rash, vomiting or flu-like }\end{array}$ & $\begin{array}{l}\text { Eye Exam } \\
\text { Eye movements }+ \text { pupillary reflex }+ \\
\text { fundoscopy }+/ \text { - visual fields }+/ \text { - acuity }\end{array}$ \\
\hline
\end{tabular}


illness.

This article is protected by copyright. All rights reserved. 


\section{University Library}

\section{- M M N E R VA A gateway to Melbourne's research publications}

Minerva Access is the Institutional Repository of The University of Melbourne

Author/s:

Lai, FWY;Kant, JA;Dombagolla, MHK;Hendarto, A;Ugoni, A;Taylor, DM

Title:

Variables associated with completeness of medical record documentation in the emergency department

Date:

2019-08-01

Citation:

Lai, F. W. Y., Kant, J. A., Dombagolla, M. H. K., Hendarto, A., Ugoni, A. \& Taylor, D. M. (2019). Variables associated with completeness of medical record documentation in the emergency department. EMERGENCY MEDICINE AUSTRALASIA, 31 (4), pp.632-638. https://doi.org/10.1111/1742-6723.13229.

Persistent Link:

http://hdl.handle.net/11343/285377 